\title{
“Hamro Jhora, Hamro Pani” (Our Spring, Our Water): Water and the Politics of Appropriation of 'Commons' in Darjeeling Town, India
}

\section{Dr. Anup Shekhar Chakraborty}

Abstract: Based on the study of Darjeeling Municipality, the paper engages with issues pertaining to understanding the matrixes of power relations involved in the supply of water in Darjeeling town in India. The discussions in the paper focuses on urbanization, the shrinking water resources, and increased demand for water on the one hand; and the role of local administration, the emergence of the water mafia, and the 'Samaj' (society) all contributing to a skewed and inequitable distribution of water and the assumption of proprietorship or the appropriation of water commons, culminating in the accentuation of water-rights deprivation in Darjeeling Municipal Area.

Keywords: Darjeeling, Hamro Jhora, Gaon Samaj, water mafia, Jal Devta, commons, politics of appropriation, India

The Town and its Water Distribution: From Colonial through Contemporary Times

Covering an area of 4.85 square miles, the town of Darjeeling is supplied with water from 26 springs (Jhoras) situated in the Senchel wildlife Sanctuary. Collected in large conduits which bring water on gravity to the storage reservoirs at Senchel namely 'North Senchel and South Senchel Lake' (Darjeeling Municipality Website). Water from the two lakes are filtered through the Jore bunglow filter house and from there the water is conveyed to the reservoirs situated at St. Paul's School Tank with the capacity of 2,35,812 gallons and the Rockville Tanks with the capacity of 56,651 gallons and 58,012 gallons each (Bomjan, 2008, 43-48). From these reservoirs, the water is distributed through pipes of varying calibre, through subsidiary tanks located at various places. An additional catchment 'Rambi Catchment Area' (RCA) that is fed by 10 springs feeds water through the Jore bunglow Filter House and brings water to the Rockville tanks. The water supply system in Darjeeling town was designed to meet the Colonial requirements with a lesser population. Over the years, the population of Darjeeling has escalated multi folds and with the growth of the township as a tourist destination the pressure is strongly felt on resources. For instance, the population increases by another 25-30 thousand floating population during the tourist season (Bomjan, 2008). This reflects the widening gap between the demand and supply of water in Darjeeling. In the lean period between 'January - May', residents of Darjeeling face an acute shortage of potable water. The springs that feed the catchments being mostly rain fed run dry during winters and this adversely affects the chain of water supply in the hill town. In order to fill the gaps in water supply at the source, water is pumped from the Khong Khola, and in addition, the collection and distribution centre at Bokshi Jhora too caters to the need of residents in and around Raj Bari area in Darjeeling town.

Due to the topography ground water seeps out from the joints and fractures of the hills in the form of springs and these alongside the municipal water supply through pipelines, forms the source of water for the town. There are 85 natural springs available within Darjeeling Municipal Area. The Darjeeling Municipality website mentions a list of 85 Jhoras in Darjeeling Municipal area. The number of Jhoras remains contested. For instance, Joshi et al, (2011) mention that there are 7 main Jhoras, 27 minor Jhoras and about $65 \mathrm{~km}$ of roadside drain within the municipal area, which starts from Jaldhapara spur and joins different streams down below. These springs provide about 20,000 gallons of water per day to the residents of the town (Rasaily, 2014). Several other drains have emerged and many subsumed, diverted and blocked dry recently due to the increased encroachment for building houses, shops, pavements, dumping garbage etc. These are of concretized encroachments on the natural pathways of water. The natural flow of these drains and outlets is severely constrained by human activity. Naturally, during monsoons the pressure is felt in and around these pathways of water resulting in landslips, drain bursts etc. Also, during dry season these natural pathways of water are conveniently used as dumping zones by the people and also the Municipality.

It is important to note that some parts of Darjeeling town, especially the upper and lower ridges (in the West) West Point, Below Mary Villa, Butcher Busty, Murda Hati, Chandmari etc., the lower and upper parts of Birch Hill, Limbu Busty, Singtam Phatak, Singamari, Rani Bun, St. Michael's, Mt. Hermon etc., (in the North), the gap in the municipal water supply system compels the residents to depend on the spring water for their existence. Interestingly there are parts of the town that depend entirely on the Municipal supply of water, areas such as Sunny Bank-Hooker Road, areas above Darjeeling Government College, TV Tower, St. Paul's, upper parts of Toongsung, Rockville, Bhote Busty, areas around Circuit House, B.Ed. College, Green Lawns etc. Again, these areas differ in degrees in terms of the 'access to procure alternative water supply' which means the difficulties in arranging alternative means of procuring 'water' to mitigate the 'water problem'. In many of these areas 'mitigating water problem' becomes a challenge 
for the simple reason that the roads are narrow bridle paths or not motorable, and at times even if motorable, the gradients do make it feasible for water tankers to move about. Here the only solution lies in the 'head load water carriers' (Pani Bhariya/Pani Bokne). These complications are further complicated in areas such as Hooker Road where even the 'head load water carriers' are not available. Further, the 'problem of water' intensely affects the aged, the infirm, the sick, pregnant women and children etc.

The several water men of the Darjeeling Municipality interviewed during 2011-2015 and also conversations with the then Chairman of Darjeeling Municipality Amar Singh Rai strongly projected the assertion that it was and is the prime duty/responsibility of the municipality to provide supplied water to the residents of the hill town. In tune with this assertion the municipality provides water to the residents of the wards through piped water in normal times and through tankers during the dry seasons. The informants from Darjeeling Municipality and the water men across the town roughly estimated that water supply connects 50 percent of the municipal households. Also, they stressed that the quantity of water supplied is limited and highly irregular across the town (Water men Interviews: Darjeeling 2010-2015). The bulk of the population of the town does not get the requisite potable water. The following selected statistical records from the Municipality shows the tensions within the supply and demand of water in Darjeeling town.

The distribution of water in the municipal area is done through a webbed network of tanks, valves and the pipe lines scattered all over the town. The water supply system in the hill town consists of about $35 \mathrm{~km}$ of transmission main lines, $83 \mathrm{~km}$ of distribution main lines (excluding the service line and public hydrants), 14 pipeline bridges along transmission mains and 90 valves scattered all over the town. The workers of the Municipality mentioned that about 95 percent of the pipelines and the valves were laid during the 'British ko palo' (colonial times). These pipelines and valves being weather beaten were in need of urgent renewal and replacement. The conversations with the water men brought to the fore the problems of 'non-maintenance', leakages, illegal tapping etc., all resulting in the loss of large volume of water and adversely affecting the water supply in the town (Water men Interviews: Darjeeling 2010-2015).

\begin{tabular}{|l|l|c|l|l|l|}
\hline 1 & Total Population & $\mathbf{1 2 0 0 0 0}$ & \multicolumn{3}{|l|}{} \\
\hline 2 & $\begin{array}{l}\text { Consumption } \\
\text { as per W.H.O } \\
\text { recommendation }\end{array}$ & 70 & \multicolumn{2}{|l|}{ Itrs/day } \\
\hline & or & 15.5 & gallons/day & gallons/day \\
\hline & Total Demand & 120000 & 15.5 & 1860000 & \\
\hline
\end{tabular}

\begin{tabular}{|c|c|c|c|c|c|}
\hline & \multicolumn{3}{|l|}{ i) Hospital } & 40000 & gallons/day \\
\hline & \multicolumn{3}{|l|}{ ii) Army } & 50000 & gallons/day \\
\hline & \multicolumn{3}{|l|}{ iii) St. Paul's School } & 20000 & gallons/day \\
\hline \multicolumn{4}{|r|}{ Total } & 1970000 & gallons/day \\
\hline \multirow[t]{3}{*}{ A } & \multicolumn{5}{|c|}{ Water Production per day } \\
\hline & \multirow{2}{*}{\begin{tabular}{|l|} 
i) $3.00 \mathrm{am}$ to \\
$4.00 \mathrm{pm}$ \\
ii) $4.00 \mathrm{pm}$ to \\
$3.00 \mathrm{am}$ \\
\end{tabular}} & 13 & 40000 & 520000 & gallons/day \\
\hline & & 11 & 30000 & 330000 & gallons/day \\
\hline & & & Total & 850000 & gallons/day \\
\hline & Wastage & $25 \%$ & & 212500 & gallons/day \\
\hline B & \multicolumn{2}{|l|}{ Net water available } & & 637500 & gallons/day \\
\hline \multirow[t]{4}{*}{ C } & \multicolumn{5}{|l|}{ Fixed supply } \\
\hline & \multicolumn{3}{|l|}{ i) Hospital } & 40000 & gallons/day \\
\hline & \multicolumn{3}{|l|}{ ii) Army } & 50000 & gallons/day \\
\hline & \multicolumn{3}{|l|}{ iii)St. Paul's School } & 20000 & gallons/day \\
\hline & & & Total & 110000 & gallons/day \\
\hline \multirow[t]{3}{*}{ D } & \multicolumn{3}{|c|}{ Water supplied to public } & & \\
\hline & \multicolumn{3}{|l|}{ Net water available } & 637500 & gallons/day \\
\hline & \multicolumn{3}{|c|}{ Deduct Fixed supply } & 110000 & \\
\hline \multicolumn{4}{|r|}{ Total } & 527500 & gallons/day \\
\hline \multirow[t]{4}{*}{$E$} & \multicolumn{3}{|c|}{ Water deficit per day } & & \\
\hline & \multicolumn{3}{|l|}{ Total demand } & 1860000 & gallons/day \\
\hline & \multicolumn{3}{|l|}{ Water available } & 527500 & gallons/day \\
\hline & \multicolumn{3}{|c|}{ Water deficit per day } & 1332500 & gallons/day \\
\hline $\mathrm{F}$ & \multicolumn{3}{|c|}{ Ratio of duration of water supplied } & 4 & days \\
\hline
\end{tabular}

Source: Annual Report(s) DMC, 2011, 2012, 2013, 2014, 2015 Sub Assistant Engineer Assistant Engineer, Water Works Department, Darjeeling Municipality; and DMC Website Total Water Demand and Supply Calculation of Darjeeling Town

Table 1: Total Water Demand and Supply Calculation of Darjeeling Town 


\begin{tabular}{|c|c|c|c|c|c|}
\hline $\begin{array}{l}\text { S. } \\
\text { No. }\end{array}$ & Reservoir & $\begin{array}{c}\text { Capacity } \\
\text { in } \\
\text { Gallons }\end{array}$ & $\begin{array}{c}\text { R.L MT } \\
\text { M.S Level } \\
\end{array}$ & $\begin{array}{c}\text { Under } \\
\text { Ground } \\
\text { Tank }\end{array}$ & $\begin{array}{c}\text { Overhead } \\
\text { Tank }\end{array}$ \\
\hline 1 & $\begin{array}{l}\text { St. Paul's } \\
\text { Tank }\end{array}$ & 235812 & $2226.0 \mathrm{~m}$ & & 235812 \\
\hline 2 & $\begin{array}{l}\text { Rockville } \\
\text { Tank (Iron) }\end{array}$ & 56651 & $2165.0 \mathrm{~m}$ & & 56651 \\
\hline \multirow[t]{2}{*}{3} & $\begin{array}{l}\text { Rockville } \\
\text { Tank } \\
\text { (Masonry) }\end{array}$ & 58012 & $\begin{array}{l}\text { Above } \\
\text { M.S level }\end{array}$ & 58012 & \\
\hline & $\begin{array}{l}\text { Subsidiary } \\
\text { Tank }\end{array}$ & & & & \\
\hline 1 & $\begin{array}{l}\text { Ghoom } \\
\text { Lower Tank }\end{array}$ & 20000 & $2403.34 m$ & & \\
\hline 2 & $\begin{array}{l}\text { Ghoom } \\
\text { Upper Tank }\end{array}$ & 20000 & 2404.0m & & 20000 \\
\hline 3 & $\begin{array}{l}\text { Retreat } \\
\text { Tank } \\
\end{array}$ & 5000 & $1981.20 \mathrm{~m}$ & 5000 & 5000 \\
\hline 4 & $\begin{array}{l}\text { Bloomfield } \\
\text { Tank }\end{array}$ & 500 & $2076.90 m$ & & \\
\hline 5 & $\begin{array}{l}\text { Kinchen } \\
\text { View Tank }\end{array}$ & 400 & $2200.65 m$ & & \\
\hline 6 & $\begin{array}{l}\text { Bhagakul } \\
\text { Tank }\end{array}$ & 10000 & $2139.69 m$ & 10000 & \\
\hline 7 & $\begin{array}{l}\text { Bokshi } \\
\text { Jhora Tank }\end{array}$ & 10000 & $1861.10 \mathrm{~m}$ & 10000 & \\
\hline 8 & $\begin{array}{l}\text { Rose Bank } \\
\text { Lower Tank }\end{array}$ & 10000 & & 10000 & \\
\hline 9 & $\begin{array}{l}\text { Bhaktay } \\
\text { Busty Tank }\end{array}$ & 500 & & 500 & \\
\hline 10 & $\begin{array}{l}\text { Clover Cot } \\
\text { Tank }\end{array}$ & 10000 & & 10000 & \\
\hline 11 & $\begin{array}{l}\text { North View } \\
\text { Tank }\end{array}$ & 5000 & & 5000 & \\
\hline 12 & $\begin{array}{l}\text { Y Building } \\
\text { Tank }\end{array}$ & 5000 & & 5000 & \\
\hline 13 & $\begin{array}{l}\text { Butcher } \\
\text { Busty Tank }\end{array}$ & 5000 & & 5000 & \\
\hline 14 & $\begin{array}{l}\text { Meadow } \\
\text { Bank } \\
\text { (Pradhan } \\
\text { Busty Tank) } \\
\end{array}$ & 10000 & & 10000 & \\
\hline 15 & $\begin{array}{l}\text { Old } \\
\text { Gymkhana } \\
\text { Tank }\end{array}$ & 10000 & $2118.05 \mathrm{~m}$ & & \\
\hline 16 & $\begin{array}{l}\text { New } \\
\text { Singamari } \\
\text { Tank }\end{array}$ & 10000 & $1895.85 \mathrm{~m}$ & & 10000 \\
\hline 17 & $\begin{array}{l}\text { Old } \\
\text { Singamari } \\
\text { Tank }\end{array}$ & 10000 & $1981.20 \mathrm{~m}$ & & 10000 \\
\hline 18 & Goflay Tank & 20000 & & 20000 & 20000 \\
\hline 19 & $\begin{array}{l}\text { Chota Ging } \\
\text { Tank }\end{array}$ & 2000 & & 2000 & 2000 \\
\hline 20 & $\begin{array}{l}\text { Bara Ging } \\
\text { Tank (10 } \\
\text { nos.) }\end{array}$ & 400 & & 400 & 400 \\
\hline 21 & $\begin{array}{l}\text { Toongsoong } \\
\text { Tank }\end{array}$ & 10000 & & 10000 & \\
\hline 22 & $\begin{array}{l}\text { Toongsoong } \\
\text { Tank }\end{array}$ & 5000 & & 5000 & 5000 \\
\hline 23 & $\begin{array}{l}\text { Bhutia } \\
\text { Busty Tank }\end{array}$ & 5000 & & 5000 & 5000 \\
\hline 24 & $\begin{array}{l}\text { Chowk } \\
\text { Bazaar Fire } \\
\text { Fighting } \\
\text { Tank } \\
\end{array}$ & 30000 & $2068.37 m$ & & \\
\hline 25 & $\begin{array}{l}\text { Mt. Verbon } \\
\text { Tank }\end{array}$ & 200000 & $2313.12 m$ & & \\
\hline \multirow[t]{2}{*}{26} & $\begin{array}{l}\text { Mahakal } \\
\text { Tank }\end{array}$ & 100000 & $\begin{array}{l}2334.46 \\
\text { m (app.) }\end{array}$ & & \\
\hline & & & & 170912 & $\begin{array}{l}369863 \\
\text { gallons }\end{array}$ \\
\hline
\end{tabular}

Source: Annual Report(s) DMC, 2011, 2012, 2013, 2014, 2015 and DMC Website List of Main Distribution Water Reservoirs and Subsidiary Distribution Tank

\begin{tabular}{|c|l|c|}
\hline $\begin{array}{c}\text { S. } \\
\text { No. }\end{array}$ & \multicolumn{1}{|c|}{ Road } & $\begin{array}{c}\text { Number of } \\
\text { Restaurants }\end{array}$ \\
\hline 1 & H.D. Lama Road & 12 \\
\hline 2 & Ladenla Road & 11 \\
\hline 3 & Nehru Road & 7 \\
\hline 4 & Gandhi Road & 6 \\
\hline 5 & Rockville Road & 6 \\
\hline 6 & Dr. Zakir Hussain Road & 20 \\
\hline 7 & J.P. Sharma Road & 6 \\
\hline 8 & N.B. Singh Road & 6 \\
\hline 9 & Bazaar Cart Road & 80 \\
\hline 10 & N.C. Goenka Road & 10 \\
\hline 11 & Judge Bazaar Cart & 6 \\
\hline 12 & Station Cart Road & 4 \\
\hline 13 & Robertson Road & 6 \\
\hline 14 & Clark Road & 2 \\
\hline 15 & B.M. Chatterjee Road & 4 \\
\hline 16 & Lebong Cart Road & 7 \\
\hline 17 & West Jawahar Road & 5 \\
\hline & & $\mathbf{1 9 8}$ \\
\hline
\end{tabular}

Table 3: List of Restaurants

Source: Annual Report(s) DMC, 2011, 2012, 2013 and own survey (2011-2015)

The distribution of water in the hilly terrain relies heavily on 'man-power', without the valve man and the 'water distribution team' it would be almost impossible to assure the steady supply of water to households in the hill town. The taps run dry in many areas of the town if the valve is not opened in a synchronized manner by valve-men at different places. Thus the 'valve man' attains an immensely crucial role in water distribution in the hill town intensely visited by the problem of 'wet drains, over flows and dry taps'. The 'valve man' or the water man (paniwala) is humorously nicknamed 'Jal Devta' (Water God/ Deity) in the hill town. The numerous interviews of the residents of various localities in the town conducted between 2011-2015 showed commonalities and connections in people's perception of water as a natural resource, a free good, a commercialised natural resource etc. These interviews also converged on a consensus on the importance of the valve man and his team of water men in Darjeeling and hence they are aptly called 'Jal Devta' (Water God/Deity) by the Nepali speaking population of the hills. Mrs. Thakuri from Hooker Road mentioned that she keeps a bottle of rum/whiskey (Indian Made Foreign Liquor (IMFL)) stocked for the Jal Devta so that he showers the regular flow of water in her four storied house (Conversation: Mrs. Thakuri, Hooker Road. 2009, 2010). Those having the right connection and mutual coordination with the Jal Devta and the staff of the municipality boastfully mentioned that they suffered "no water crises and that pani ko samasya ('problem 
of water') was a problem associated with 'those who could not afford to buy water' and those 'too stingy to buy water'. 'There is so much water to buy; these people who crib that there is water crises are those who are stingy to solve the problem by buying it. We live on the $6^{\text {th }}$ floor and have running water $24 \times 7$. We have three connections and unlimited supply of water all it takes is to keep the Jal Devta happy with money and rum'. (Conversations: Mr and Mrs. Chhetri. Youth Hostel, TV Tower. 2011-12) 'Kina dhukha garie basne, pani ta kinnu pauchan, hami le pani saal bhari pani kinera chal deichu ta' (Why fret and sulk over water, water can be purchased readily, even we buy water all through the year) (Conversation: Mrs. Shashankar Landlady Dolls Dream, Rockville, TV Tower. 2015). The conversations of water and the conversations of pani ko dukha, pani ko samasya reflect the variations in the degrees in which water (both its availability, and the lack of it) effects people differently.

\section{The 'Problem of Water' (Pani ko Samasya)}

An increasing gap between the demand and supply of water and subsequent failure of the planned efforts by the Municipality and the government to meet the basic needs of water has added to the 'problem of water' (pani ko samasya) in Darjeeling. The 'problem of water' has innovatively unleashed entrepreneur opportunism in the form of 'water businesses'. Water vendors are commonly seen in the study area (Darjeeling town) operating without any legal framework. 'Selling water' (pani bechne) has become a profitable business in Darjeeling today (Guha and Kujur, 2009). Water business has added an employment opportunity for many unemployed youths in Darjeeling as this has become one of the easiest mode of earning. The 'problem of water' (pani ko samasya) and the urgency to find a hassle-free solution ('pani ko samadhan') has resulted in the emergence of the 'Water Mafia' 'selling water (pani bechne). I call them 'water mafia' precisely because their tendency to create a crunch in water and compel the residents to buy water (which is a commons) at exorbitant price. The water crisis is a man made one and the samadhan (solution) in the form of rain water harvesting has not been able to enter the social imaginaries of the residents because of the false propaganda by the 'water mafia' and their nexus that 'harvested water' through rain water is 'basi paani' (stale water) and therefore unfit for human consumption.

Those interviewed cutting across class, gender, caste, religion etc., strongly felt that insufficient and unreliable supply by the MWSI to meet the demand of water in the town have compelled the people of Darjeeling to choose the only alternative source of drinking water available that is the nexus of the private suppliers and 'water mafia'. The study revealed that on an average 75 percent of consumers depended on private vendors for the need of water. The private water vendors play a very important role when it comes to meet the needs of water, mainly during the dry seasons when the scarcity of water goes up. Therefore, during the dry season when the supply of water becomes limited, there is no other option left to the consumers except for depending on private water suppliers (Interviews of shopkeepers and restaurant owners in Beech Gully (2009-2011); Interviews of restaurant owners in Singamari, Toongsoong, H.D. Lama Road, etc. (2009-2013); Conversations with residents of various locations in Darjeeling town (2009-2015). Names and details withheld on request). These respondents also mentioned that the nexus of private suppliers and water mafia having a strong link and support of the parties in power that is during the Chhiyasi ko Andolan (1986 Movement) it was those connected with the GNLF and now in the current imbroglio (stretched from 2007 to 2017) those with the GJMM. The political parties and their leaderships gave lip service to address and solve the problem of water while in the late 80 s -through the 90s the prominent leader (Subhas Ghisingh) promised to supply surplus water and build swimming pools atop each house in Darjeeling; in the mid 200os the changed leadership (Bimal Gurung) sold the dreams of seamless flow of water through the Balason and packaging the Himalayan waters in a bottle.

The answers gleaned from the respondents in the field further revealed that though all categories of consumers (household, commercial, institutional) depended on private vendors/'water mafia' to meet their everyday demands of water, the dependency of commercial consumers turn out to be much higher as compared to other consumers. This gap in the Pani ko samasya and the samadhan opens the door for the heightened role of a variety of private water vendors/suppliers in Darjeeling town such as:

\section{The Pani Bhariya (Water Carrier)}

Porters ('Coolies') and water carriers who are locally referred to as 'bhariya', 'namley' 'bhari bokney' in most cases hail from Nepal and Indo-Nepal border areas; and they play crucial role in the supply and sale (commercialization) of water (Informal discussion: Mann Bahadur, 2009-14). These migrants from Nepal like Mann Bahadur himself are in most cases 'illegal migrants' and form a large section of the unskilled labour force of the hill economy. Uncertainty over their status makes them vulnerable to the dictates of the men who control the resources and the distribution of the same. These water carriers supply in jerry cans to individual houses and both men and women are engaged in this business. For instance, these bhariyas collect water from 'created leaks' or 'breaks' in supply pipes chain or supply water stored in private reservoirs. The rate of head-load differs seasonally and in most cases monthly supply is opted. A 60 litre jerry can of water is rated at 70-90 rupees (Toongsoong 2011 rate) while a monthly supply of the same amount of water is priced at 1300-1500 rupees (2011 rate). It is pertinent to note that the rate chart differs from place to place depending upon the distance 
from the supply pipe and the leak chain.

The exorbitant rate of water supplied through head load makes water a premium. In fact, bottled water remains cheaper than water supplied by bhariyas in few areas of the town of Darjeeling. Few of my respondents mentioned that during peak season (tourist season) in areas where water trucks are inaccessible opting for bottled water in place of water supplied by head loads remains a cheap alternative.

The bhariya are generally small scale water sellers. They walk the distance and deliver water to the people's home and sell water on small quantity. These types of vendors are usually men or women who collect water from the perennial and non perennial springs located within the town. The quantity of these jerry cans ranges from fifteen to twenty litres. They usually carry one or two jerry cans in a single trip. The price of water depending upon the distance travelled ranging from Rs 25 to Rs 40 per jerry can (Toongsoong rates 2011, 2012, 2013, 2014 and rupees 40 Rockville rate 2015).

\section{The Hand Carts Vendors (HCV)}

This is an exclusively male enterprise demanding physical strength to push and pull the wooden carts updown the bridle paths in the hill town. I did not find any female engaged in hand cart vendoring of water during my field study. The hand cart vendor's use 'Gorkhey Jeep' (wooden cart with improvised wheels and wooden jammers for break) for the supply of water. Each cart holds 16 to 18 buckets approximately 250 litres and priced at rupees 100 for a cart full. The price of cart is fixed in tune with the distance to be covered for transportation.

The HCV supply of water in the town is also dominated by labour migrants from Nepal. The HCVs collect water from the springs located within the town or procure water from the Water Tanker Suppliers (WTS) and sell water in hand carts for a marginable profit. The water from the springs comes free while they pay Rs 50 for 250 litres when procured from water tankers. These are then sold for a maximum profit depending on the distance and the regularity of the supply demanded. Most of the small eateries, tea stalls, restaurants in the old supermarket, new super-market, and the beef market etc., rely on these hand cart vendors for their everyday supply of water. The HCVs supply water to the petty businesses and are paid either daily or weekly or in 15 days or at the end of the month.

The HCV normally earns between Rs. 500 to 600 a day by selling water. Procuring water becomes a challenge during the dry spell mainly because the Gaon Samaj prohibits day time collection of water for the HCV from the springs in the town. The HCVs during the dry spell collect water at night and continue the supply chain during the mornings. The HCV supply water between 5:30 am - 7:30 am and sometimes at night after $8 \mathrm{pm}$.
The HCV have to negotiate their everyday business with a clandestine understanding with the traffic police of Darjeeling. Out of the 10 individuals interviewed, 6 belonged to the Thami community from Nepal and 4 brought their wives along. Their wives worked as wage labourers, cleaners (mainly dish washers) in marriage parties and ceremonies related to death, porters etc.

\section{The Water Tanker Supplier (WTS)}

These water suppliers use Tankers to supply water. The volume of the supply makes them the cheapest amongst the choices available to mitigate the pani ko samasya. The WTSs collect water from the jhoras and dharas from the outskirts of Darjeeling and sell water in tankers in parts of the town where the vehicles can be navigated. Water tanker business has become lucrative and many people in Darjeeling are seen converting their trucks to sell water. Approximately about 120 trucks and 30 saavari pickups are engaged in selling water in the town. During the dry season a fleet of these WTSs loads three to four trips of water in a day with the capacity of 5500 to 6500 liters of water per trip. During the rest of the year 60 to 65 trucks ply every day. Few drivers mentioned that they jokingly tell the Jal Devta: 'You don't supply, we sell!'

\section{The Private Springs Owners (PSO)}

These are the fourth category of suppliers available in Darjeeling to mitigate the problem of water. They are mainly direct vendors who sell water to the consumers through pipes snaking from the spring's source located at their private area. Selling of water from these is one of the easiest and profitable means of earning to the people of Darjeeling. The areas in lower Toongsung, Ganesh Gram, Alubari, Japanese Temple, Nimki Dhara etc., thrive on this business.

What can be construed from the above discussions is that 'in the samadhan (solution) also lies the problem'. Besides these suppliers/vendors 'Tapping water by boring holes into the pipe lines' is a common phenomenon in the hills. These illegal tappers divert water by drilling holes into the several municipal pipe lines and insert hose pipes to tap water. These are then sold to feed into the demand chain.

Alongside these myriad water supply and chain of vendors, we also find an emergent entrepreneurship in 'bottling the water' from the hill springs and catering to specific demands both in the hills and the plains below. These entrepreneurs package the water from the Himalayas in 'bottles' and skilfully capitalize and market 'health, nature, and the pristine Himalayan climes'. In the absence of any regulatory norms or agencies the water sources (resources) in the hills is exploited and run the risk of over-exploitation (The Darjeeling Chronicle. 15 September 2014). Bottled water supplied from Siliguri 
and adjoining areas cater to the demands of high-end water demand. Hotels, restaurants and shops keep stock of bottled water (mineral water) for this section of demands.

\section{Policing Water: The Gaon Samaj and Control over Water Commons}

Yo 'Hamro Jhora, Hamro Pani' ho! (This is our springs, our water!)

The above claims to 'water' and the 'Jhora' in Darjeeling forms parts of the everyday conversations and arguments at water sources, these conversations are laced with belittling of communities and otherisation. Here the issue of portability of water is not a concern. Water of any type especially if clear and not muddy is the criteria. Even muddy water is severely sought for and put to fringe use within the household in Darjeeling town. The contests and claims to commons can be seen even at the level of the administrative/distributive. For instance the Jhoras (perennial springs) located within the municipal boundaries are severely contested by the various actors in the town. While officially these do not fall within the purview of the municipality it can be observed (as seen from the Jhora list maintained by the Municipality) that the municipality is keen to take charge over the natural resource. Most of these springs are managed by 'localized vigilant residential communities' or rudimentary Community Based Organisations (CBOs) known as Gaon Samaj. Around 130 different Gaon Samaj (Joshi et al, 2011) located within the boundaries of municipal wards provide additional civic services where the municipality remains inactive.

\begin{tabular}{|c|l|c|c|c|c|}
\hline $\begin{array}{c}\text { S. } \\
\text { No. }\end{array}$ & Name of Jhora & $\begin{array}{c}\text { Ward } \\
\text { No }\end{array}$ & $\begin{array}{c}\text { Length } \\
(\mathbf{m})\end{array}$ & $\begin{array}{c}\text { Width } \\
(\mathbf{m})\end{array}$ & $\begin{array}{c}\text { Total } \\
\text { Area }\end{array}$ \\
\hline 1 & Holmdene Jhora & 31 & 658.36 & 2.45 & $1,612.98$ \\
\hline 2 & Thendup Jhora & 31 & 243.84 & 1.85 & 451.10 \\
\hline 3 & Bhutia Jhora & 31 & 213.36 & 1.50 & 320.04 \\
\hline 4 & $\begin{array}{l}\text { Slaughter House } \\
\text { Jhora }\end{array}$ & 18 & 457.20 & 2.40 & $1,097.28$ \\
\hline 5 & $\begin{array}{l}\text { Jhora near } \\
\text { Carmicheal Road }\end{array}$ & 28 & 152.40 & 1.85 & 281.94 \\
\hline 6 & Diocean Jhora & 28 & 396.24 & 0.92 & 364.54 \\
\hline 7 & $\begin{array}{l}\text { Happy Valley } \\
\text { Jhora }\end{array}$ & 28 & 701.04 & 2.42 & $1,696.52$ \\
\hline 8 & $\begin{array}{l}\text { Jhora near Toong } \\
\text { Soong School }\end{array}$ & 14 & $2,133.60$ & 1.52 & $3,243.07$ \\
\hline 9 & $\begin{array}{l}\text { Jhora near } \\
\text { Buddhist } \\
\text { Monastery }\end{array}$ & 14 & 213.36 & 1.84 & 392.58 \\
\hline 10 & $\begin{array}{l}\text { Jhora near Mt. } \\
\text { Everest }\end{array}$ & 9 & 304.80 & 0.90 & 274.32 \\
\hline 11 & $\begin{array}{l}\text { Jhora near B.T. } \\
\text { College }\end{array}$ & 9 & 182.88 & 1.83 & 334.67 \\
\hline 12 & $\begin{array}{l}\text { Raj Bhawan } \\
\text { Jhora }\end{array}$ & 30 & 396.24 & 1.22 & 483.41 \\
\hline 13 & $\begin{array}{l}\text { Botanical Garden } \\
\text { Jhora }\end{array}$ & 26 & 182.88 & 3.05 & 557.78 \\
\hline 14 & Juman Jhora & 19 & 274.32 & 1.51 & 414.22 \\
\hline 15 & $\begin{array}{l}\text { Chevorment } \\
\text { Jhora }\end{array}$ & 1 & 167.64 & 1.83 & 306.78 \\
\hline
\end{tabular}

\begin{tabular}{|c|c|c|c|c|c|}
\hline 16 & $\begin{array}{l}\text { Bangla Jhora } \\
\text { near } 190 \text { Cart } \\
\text { Road }\end{array}$ & 1 & 169.52 & 1.83 & 310.22 \\
\hline 17 & Rajhatta Jhora & 1 & 121.92 & 1.22 & 148.74 \\
\hline 18 & \begin{tabular}{|} 
Jhora near Lakpa \\
Sardar House'
\end{tabular} & 4 & 182.88 & 1.22 & 223.11 \\
\hline 19 & \begin{tabular}{|l|}
$\begin{array}{l}\text { Lungtham Jhora } \\
\text { (Singamari) }\end{array}$ \\
\end{tabular} & 28 & 259.08 & 2.43 & 629.56 \\
\hline 20 & $\begin{array}{l}\text { Jhora leading } \\
\text { W.J.Rd. to I.D. } \\
\text { Hospital }\end{array}$ & 28,29 & 609.60 & 1.22 & 743.71 \\
\hline 21 & $\begin{array}{l}\text { Jhora W.J. Road } \\
\text { to P.G. Road }\end{array}$ & 28,29 & 792.48 & 1.21 & 958.90 \\
\hline 22 & Lochnagar Jhora & 23 & 853.44 & 0.91 & 776.63 \\
\hline 23 & \begin{tabular}{|l|} 
Lal Dhiki (Society \\
Jhora)
\end{tabular} & 22 & 243.84 & 1.22 & 297.48 \\
\hline 24 & Hospital Jhora & 22,23 & $1,005.84$ & 1.23 & $1,237.18$ \\
\hline 25 & Jiten Jhora & $\begin{array}{c}24,25 \\
26 \\
\end{array}$ & $1,066.80$ & 2.43 & $2,592.32$ \\
\hline 26 & Brynwyn Jhora & 19 & 707.13 & 3.64 & $2,573.95$ \\
\hline 27 & Banstead Jhora & 19 & 335.28 & 2.43 & 814.73 \\
\hline 28 & Cromline Jhora & 17 & 640.08 & 1.84 & $1,177.75$ \\
\hline 29 & Belombre Jhora & 16,17 & 792.48 & 2.42 & $1,917.80$ \\
\hline 30 & $\begin{array}{l}\text { Rockwood Jhora/ } \\
\text { Queen's Hill }\end{array}$ & 12 & 152.40 & 1.53 & 233.17 \\
\hline 31 & $\begin{array}{l}\text { Rockwood Jhora/ } \\
\text { Himachal Jhora }\end{array}$ & 16 & 121.92 & 1.50 & 182.88 \\
\hline 32 & Merry Villa Jhora & 7 & 762.00 & 2.43 & $1,851.66$ \\
\hline 33 & Saipatri Jhora & 7,8 & 914.40 & 2.43 & $2,221.99$ \\
\hline 34 & \begin{tabular}{|l|}
$\begin{array}{l}\text { Dali Petrol Pump } \\
\text { Jhora }\end{array}$ \\
\end{tabular} & 5 & 609.60 & 3.05 & $1,859.28$ \\
\hline 35 & Bokshi Jhora & 5 & 304.80 & 2.43 & 740.66 \\
\hline 36 & Durga Jhora & 8 & 304.80 & 1.83 & 557.78 \\
\hline 37 & Saraswati Jhora & 8 & 243.84 & 3.66 & 892.45 \\
\hline 38 & $\begin{array}{l}\text { Cremation ghat } \\
\text { Jhora, Dali }\end{array}$ & 5 & 304.80 & 2.43 & 740.66 \\
\hline 39 & $\begin{array}{l}\text { Jhora above Ging } \\
\text { Bazaar }\end{array}$ & 32 & 243.84 & 1.85 & 451.10 \\
\hline 40 & Holy Gaon Jhora & 14 & 243.84 & 2.43 & 592.53 \\
\hline 41 & $\begin{array}{l}\text { Jhora near Kripa } \\
\text { Centre }\end{array}$ & 31 & 243.84 & 1.80 & 438.91 \\
\hline 42 & $\begin{array}{l}\text { N.B.M.R. Jhora } \\
\text { (lower) }\end{array}$ & 31 & 310.94 & 3.05 & 948.37 \\
\hline 43 & Lower Rockwood & 16 & 95.60 & 1.53 & 146.27 \\
\hline 44 & $\begin{array}{l}\text { Garidhura Jhora } \\
\text { Jore bunglow }\end{array}$ & 1 & 121.92 & 1.83 & 223.11 \\
\hline 45 & $\begin{array}{l}\text { Gopal Jhora, Jore } \\
\text { bunglow }\end{array}$ & 1 & 76.20 & 22 & 92.96 \\
\hline 46 & $\begin{array}{l}\text { Jore bunglow } \\
\text { Beech Gaon }\end{array}$ & 1 & 152.40 & 1.83 & 278.89 \\
\hline 47 & Chamtaling Jhora & 1 & 121.92 & 2.45 & 298.70 \\
\hline 48 & $\begin{array}{l}\begin{array}{l}\text { Martin dispensary } \\
\text { Jhora }\end{array} \\
\end{array}$ & 2 & 152.40 & 2.45 & 373.38 \\
\hline 49 & $\begin{array}{l}\begin{array}{l}\text { Dilmaya Busty } \\
\text { (Mochi) Jhora }\end{array} \\
\end{array}$ & 2 & 152.40 & 2.40 & 365.76 \\
\hline 50 & \begin{tabular}{|l} 
Ghoom \\
Monastery Jhora
\end{tabular} & 3 & 152.40 & 2.43 & 370.33 \\
\hline 51 & $\begin{array}{l}\text { D.R.C. Jhora } \\
\text { Sukhia Road }\end{array}$ & 3 & 121.92 & 2.45 & 298.70 \\
\hline 52 & $\begin{array}{l}\text { Sherpa Gumba } \\
\text { Jhora }\end{array}$ & 3 & 182.88 & 2.41 & 440.74 \\
\hline 53 & Hissay Khola & 2 & 91.44 & 2.44 & 223.11 \\
\hline 54 & $\begin{array}{l}\text { Ghoom Boy's } \\
\text { School }\end{array}$ & 4 & 121.92 & 2.44 & 297.48 \\
\hline 55 & Bheri Khan Jhora & 2 & 137.16 & 2.44 & 334.67 \\
\hline 56 & Rai Villa Jhora & 30 & 213.36 & 1.84 & 392.58 \\
\hline 57 & \begin{tabular}{|l} 
Karma Garage \\
Jhora
\end{tabular} & 4 & 243.84 & 1.80 & 438.91 \\
\hline
\end{tabular}




\begin{tabular}{|c|l|c|c|c|c|}
\hline 58 & Batasia Jhora & 4 & 182.88 & 1.53 & 279.81 \\
\hline 59 & $\begin{array}{l}\text { St. Michael } \\
\text { School Jhora }\end{array}$ & 29 & 352.75 & 1.80 & 634.95 \\
\hline 60 & Goenka Jhora & 5 & 152.40 & 3.10 & 472.44 \\
\hline 61 & $\begin{array}{l}\text { Gumba Jhora H. } \\
\text { C. Road }\end{array}$ & 5 & 152.40 & 3.05 & 464.82 \\
\hline 62 & $\begin{array}{l}\text { Gumba Jhora } \\
\text { Dali }\end{array}$ & 6 & 185.65 & 2.00 & 371.30 \\
\hline 63 & Naga Jhora, Dali & 6 & 91.44 & 1.85 & 169.16 \\
\hline 64 & $\begin{array}{l}\text { Thapa Cottage } \\
\text { Jhora }\end{array}$ & 6 & 152.40 & 1.83 & 278.89 \\
\hline 65 & West Point Jhora & 5 & 121.92 & 2.45 & 298.70 \\
\hline 66 & Maharani Jhora & 16 & 182.88 & 3.05 & 557.78 \\
\hline 67 & Convent Jhora & 23 & 914.40 & 3.05 & $2,788.92$ \\
\hline 68 & Mayfair Jhora & 30 & 304.80 & 3.05 & 929.64 \\
\hline 69 & $\begin{array}{l}\text { Govt. College } \\
\text { Jhora }\end{array}$ & 27 & 152.40 & 1.83 & 278.89 \\
\hline 70 & $\begin{array}{l}\text { Scott. Mission } \\
\text { Jhora }\end{array}$ & 28 & 304.80 & 1.83 & 557.78 \\
\hline 71 & Helukay Jhora & 28 & 609.60 & 1.52 & 926.59 \\
\hline 72 & $\begin{array}{l}\text { T.O.P. Jhora } \\
\text { (Singamari) }\end{array}$ & 29 & 365.76 & 1.23 & 449.88 \\
\hline 73 & Retreat Jhora & 5 & 350.52 & 1.66 & 581.86 \\
\hline 74 & $\begin{array}{l}\text { Miss. Compound } \\
\text { to Senchal Rd. } \\
\text { Jhora }\end{array}$ & 1 & 120.65 & 2.00 & 241.30 \\
\hline 75 & $\begin{array}{l}\text { Monastery Jhora } \\
\text { Aloobari }\end{array}$ & 13 & 65.40 & 1.60 & 104.64 \\
\hline 76 & $\begin{array}{l}\text { Bhotay Dhara } \\
\text { Jhora }\end{array}$ & 29 & 156.80 & 1.50 & 235.20 \\
\hline 77 & Lhasa Villa Jhora & 7 & 135.00 & 1.80 & 243.00 \\
\hline 78 & Stardust Jhora & 31 & 185.60 & 1.85 & 343.36 \\
\hline 79 & $\begin{array}{l}\text { Frymal Village } \\
\text { Jhora }\end{array}$ & 27 & 305.35 & 1.00 & 305.35 \\
\hline 80 & $\begin{array}{l}\text { Chinese } \\
\text { Cementery Jhora }\end{array}$ & 4 & 250.65 & 1.00 & 250.65 \\
\hline 81 & Rose Bank Jhora & 7 & 213.36 & 2.43 & 518.46 \\
\hline 82 & $\begin{array}{l}\text { Latte Lama } \\
\text { Gumpa } \\
\text { Jhora,T.N. Road }\end{array}$ & 14 & 457.20 & 1.82 & 832.10 \\
\hline 83 & Titanic Jhora & 14 & 152.40 & 1.83 & 278.89 \\
\hline 84 & Masonic Jhora & 14 & 152.40 & 1.83 & 278.89 \\
\hline 85 & $\begin{array}{l}\text { Jhora near } \\
\text { Tikaram Bldg }\end{array}$ & 8 & 75.00 & 1.75 & 131.25 \\
\hline & $\mathbf{2 8 4 . 1 2}$ & $\mathbf{5 6 , 3 2 4 . 9 8}$ \\
\hline
\end{tabular}

Table 4: Official List of Jhoras in Darjeeling Town as Shown by the Darjeeling Municipality

Source: DMC Website List of Jhoras

These 'Goan Samaj' are self funding organizations collecting small amount of money in term of membership subscriptions/fees. These Samaj take onto themselves the responsibility of management (maintenance and distribution) of the springs located within their ward and also ration the volume of water that people can draw from the spring. This rationing comes useful especially during the dry seasons when the volume of water decreases drastically. Socio-religious groups also play an important role in the 'protection', maintenance of cleanliness and everyday use of the springs. None of these Samaj takes care of more than one spring. As the official (municipal) water supply is unpredictable and

insufficient, people located within the periphery of the town depends on these spring water. In regard to the management of springs various conservation measures have been adopted by the Samaj like construction of storage tanks, organizing afforestation programs (every six months), controlling and limiting dumping into the Jhoras, checking human activities around the Jhoras etc. Water is made available to residents within the wards and also to those from other wards during the rainy season. However, during the dry spell in Darjeeling certain rules and regulations are imposed such as: i) people from outside the wards are not allowed to collect water from the spring, ii) washing clothes and bathing are prohibited in the spring during the dry season, iii) the timing and quantity is fixed for the collection of water iv) distribution of water is done through jerry can queue system. These rules and regulations are aimed to provide equal share of water even during the time of scarcity. Apart from these Samaj, religious organizations like Sai Samity, Church bodies also play an active role in cleanness, management and maintenance of these springs.

Sustainable management of water resource in Darjeeling is effected by hurdles in decision making, lack of funds, lack of transparency and information sharing, relationship between political stability and governance, and self-organized grass roots level organizations etc. The decision making process in terms of water resource management in Darjeeling at the municipal level is highly centralized, bureaucratic in nature and observed the everyday pace of the office bearers is sickly slow. Multiple issues gel into making the task of distribution and management of water resources in Darjeeling a challenging one. The most prominent factor besides the administrative and municipal apathy is the nonconsensus of the different Samaj and religious bodies; followed by the residents/peoples' perception of water and its samasya etc.

\section{Politics of Water and Otherisation in the Hills of Darjeeling}

Water is a strange natural resource it can unite a community as easily as it can divide it. (Indira Khurana , 2003).

In this section I drive forward my argument that the water crunch or 'pani ko samasya' in the Darjeeling hills effects people differently. The 'samasya' has not changed much of its viscosity when it comes to water and the 'Bahira ko manchhe' ('Outsiders'). The outsiders remain largely at the receiving end of water, potable or otherwise. The everyday occurrences and conversations at the dahras, jhoras speaks in volumes about how water cultures or cultures of water are shaped by people. My interviews with the 'outsiders' accentuated very interesting takes on water and water rights as experienced in everyday life in the hills. For instance, Sashi (Personal 
Interview. Darjeeling 2011) narrated her childhood experience of having to wait for hours at the dhara. According to Sashi, "children were the most affected by the politics of water at play in Darjeeling". She recalled that on numerous occasions an elderly woman belonging to the Nepali speaking community would assert her right on water and shove her aside while shouting:

"hamropani ho...Madeshi haru le ailey thapnu paudeina ...aapnu trun parkho" ('it is our water... Madeshi aren't supposed to collect water now...wait for your turn').

Claims to ownership of 'commons' is largely reflected through these conversations and also the spatial zoning or mapping of people especially the 'Others' is strongly reflected through these everyday conversational exchanges among residents of the select areas. My interviews with the 'outsiders' also accentuated that 'water' preoccupied the everyday experiences of women and children than men in general in the hills. All this further substantiates and adds to the understanding that women and children are actively engaged in the collection and storage of water and therefore their experiences surrounds the realities of politics of water at play in ground zero. Men on the other hand seem to be aloof from the complexities of water collection, storage and management though men monopolize the control of the water sources, the supply and are largely responsible for the commercialization of water. The claims to commons and ownership of commons can be gleaned from the everyday conversations and exchanges at water sources in Darjeeling like the ones mentioned below:

Kina ako timi haru? Ahile na au,ja gharja! Yo (Why have you all come now? Go home, go home!);

Apuii Yo Madeshi haru le kati pani thapnu sakeko. (Oh my, these Madeshis consume so much water.)

Even local (native Nepali speaking) children narrated similar experiences of having to wait for long hours and being rebuked by elders at the dhara and jhoras. Children supplied 15 litres of water in one turn and made 3 to 6 rounds in a day. Beyond the concerns of health and water on children I would point out that 'pani ko samasya' and its effects on children in Darjeeling town deep. My study pointed that 'Water problem' has strong connection with the drop-out rates and late arrival (irregularity) of children in schools and colleges in Darjeeling. For instance, missing 9 am classes in schools and colleges and having to pay fines to regularize their irregularity at scheduled times in the educational institutions is a common experience of students in the hills. This compensation action of 'paying fines' has a direct link to the larger hill economy manifest at two levels, first the individual household and second the collective level. The money diverted to these fines could have substantiated the dwindling household economy of the individual houses of the hills had the issue of water management and equitable distribution been taken care with a serious note. Next the elders seemed to dominate children from across the local-outsider variation; and also women in their variegated existence had close encounters with water crunch. A third angle, that is always missed is that either in the form of 'fines', or payment for procuring water etc., somebody is making a profit out of a free natural resource, and that somebody is always a part of the nexus of the private suppliers, 'water mafia', the politically connected and the economically dominant (and in that sense the elite).

\section{Some Closing Observations}

It can be clearly understood from the above discussion that the boon of heavy rainfall (strategic advantage of being located in a high rainfall area) has not been converted to a potential due to a matrix of inter-woven issues/factors. Dry spells and dry taps have become the lived reality of the town of Darjeeling. In spite of the presence of sufficient number of resources to sustain the need of the people, the authorities, the political nexus and the people as a community has been unable to harness these resources to make them adequate for drinking purpose. This is strongly indicated through the study of roof top rain water harvesting in Darjeeling and the impossibility of the idea catching the social imaginaries of the residents and administrators. Though the study on rain water harvesting and the practical instance put to operation at the Raj Bhawan Darjeeling should have had an imitation effect across the hill town unfortunately the myths circulated has resulted in a negative one. My respondents mentioned that 'rain water harvesting' was not suited for Darjeeling, and gave a series of negative effect that rain water harvesting could have on the town and its people (most of them also mentioned that the Jal Devtas, and the water tanker suppliers etc., had told them so) that it would cause landslides, weaken the soil, the stored rain water was unfit for human consumption even after filtration etc. All these adds to the greater understanding that social imaginaries are steeply grooved into the political, and that social change and acceptance of innovation is time taking, gradual process, and exasperating; also that 'hydro-politics' in the hill station of Darjeeling is hooked to the politics of 'who gets what through the politics of nexus and networking'.

\section{Acknowledgement}

I thank the UGC for the grant received for conducting this study (Minor Research Project 2011-12) 'Comparisons, Contrasts \& Contortions: Politics of Water in The Hill Stations of Darjeeling and Kalimpong'. The discussions in this paper are parts of the report of the field study conducted in Darjeeling and Kalimpong (2011-2012); and an extension of the same study in Darjeeling town through 2015 . 
Dr. Anup Shekhar Chakraborty is currently a faculty in the Department of Political Science and Political Studies, Netaji Institute for Asian Studies (NIAS), Kolkata, India. Previously he was faculty at the Department of Political Science, St. Joseph's College, Darjeeling (University of North Bengal). He is an alumnus of St. Xavier's College, Kolkata and University of Calcutta.

He represented India at the CODESRIA/ SEPHIS 'Workshop for Young Historians' (Dakar, Senegal) 20o6. He was the recipient of IDRC, Digital Empowerment Foundation (DEF) and India Development Foundation 'India Social Science Research Award 2009'.. He received the prestigious C.R. Parekh Fellow (2011-2012) at Asia Research Centre, London School of Economics \& Political Science for his post doctoral research initiative titled: 'Contested Landscape and Befuddled Public Sphere: Media, Democracy and Public Participation in Darjeeling Hills'. He has to his credits, several publications dealing with interesting aspects of North East India in renowned journals. He authored Politics of Autonomy \& Ethnic Cocooning in Mizoram. (2015, New Delhi: Authorspress) and Hegemony to Hyphenation: Hybridization of Identities and Politics in Mizoram. (2015, Darjeeling: St. Joseph's Publication). He also co-edited (with Padam Nepal) Politics of Culture, Identity and Protest in North-east India (2012, Vol. 1 \& 2. New Delhi: Authorspress) and (with Padam Nepal) Politics of Exclusions and Inclusions in India: Construing Commonalities and Complexities. (2016, New Delhi: Authorspress).

CorrespondingE-mail:anupshekharc@rediffmail.com

\section{References and Bibliography}

'A Report on Water Supply System of Darjeeling Municipal Area'. Darjeeling Municipality Website http://darjeelingmunicipality.in/ accessed on 08/11/2017

'List of Jhoras'. Darjeeling Municipality Website http:// darjeelingmunicipality.in/ accessed on 08/11/2017

'List of Main Distribution Water Reservoirs and Subsidiary Distribution Tank' Darjeeling Municipality Website http://darjeelingmunicipality. in/ accessed on $08 / 11 / 2017$.

'Bimal Gurung Announces Packaged Drinking Water and Other Plans for Darjeeling'. The Darjeeling Chronicle. 15 September 2014.

Bahadur, J. (1998). Water Resource Management in the Himalayan Region. http://www.mtnforum. org/sites/default/files/publication/files/67.pdf. (Accessed on 14 October, 2013).
Bomjan, D. S. (2008). Darjeeling -Doors People under Bengal Neo-Colonial Rule. Darjeeling: Bikash Jana Sahitya Kendra.

Chakraborty, Anup Shekhar. (2015)."Becoming 'Local': Muslims and the Politics of the 'Local' and the 'Nonlocal' in Darjeeling Hills”. Refugee Watch. Vol. 46. December, 2015. pp. 21-35;

Chakraborty, Anup Shekhar. and Subhas Ranjan Chakraborty. (2016) 'Ambiguous Identities: Statelessness of Gorkhas in North-East India' in Paula Banerjee, Anasua Basu Ray Chaudhury \& Atig Ghosh, (Ed.). (2016). The State of Being Stateless: An Account of South Asia. New Delhi: Orient Black Swan Pvt. Ltd. pp.207-245;

Darjeeling Municipality. (2010, 2011, 2012, 2013, 2014, 2015). An Annual Report(s) of Darjeeling Municipality.

Das, S. (2010). Water Crisis in Darjeeling Town. Indian Journal of Landscape System and Ecological Studies, 33 (1), 121-128.

Dash, A. J. (1947). Bengal District Gazetteer. Siliguri N.L. Publishers

Datta, K. (Ed). (2006). Urbanization in the Eastern Himalayas: Emergence and Issues. New Delhi: Serials Publications.

Dozey, E. C. (2011). A Concise History of the Darjeeling District since 183. Siliguri: N.L. Publishers.

Guha, R. K., and Kujur, Anita. R. (2009). Roof top rainwater conservation in Darjeeling town an option to mitigate the crisis of water supply-A Case Study of Raj Bhawan Darjeeling, West Bengal. Bhu-Jal News Quarterly journal, 24 (1), 85-90.

Joshi, D., Rai, S. K., and Samuel, T. (2011). The Perennial Springs of Darjeeling, a survey to community based conservation. Ashoka Trust for Research in Ecology and Environment (ATREE), Eastern Himalayas Program Darjeeling .Darjeeling, India.

Khurana, Indira. (2003). 'Water Scarcity? Try Capturing the Rain', Chapter 13, 137-147 in Kamta Prasad. (2003). Water Resources And Sustainable Development. New Delhi: Shipra Publications.

O'Malley, L.S.S. (1907). Darjeeling District Gazetteers. New Delhi: Logos Press.

Ostrom, Elinor, Walker, James., and Roy Gardner. (1994).Rules, Games, and Common-Pool Resources. Ann Arbor: University of Michigan Press.

Ostrom, Elinor. (1990). Governing the Commons: The Evolution of Institutions for Collective Action. Cambridge: Cambridge University Press.

Rasaily, D.S. (2014). Darjeeling Paharka Nagarpalika Kshetra ko Vikash Ra Khane Pani Ko Itihas Sanchipta Ma , San.1835-2012. New Delhi.

Shiva, Vandana. (2002). Water Wars: Privatization, Pollution and Profit. Cambridge, MA: South End Press.

Singh, Chhatrapati.(1991). Water Rights and Principles of Water Resource Management. Bombay: N.M. Tripathi. 